\title{
Long Noncoding RNAs: At the Intersection of Cancer and Chromatin Biology
}

\author{
Adam M. Schmitt ${ }^{1}$ and Howard Y. Chang ${ }^{2}$ \\ ${ }^{1}$ Department of Radiation Oncology, Memorial Sloan Kettering Cancer Center, New York, New York 10065 \\ ${ }^{2}$ Center for Personal Dynamic Regulomes, Stanford University School of Medicine, Stanford, \\ California 94305 \\ Correspondence: howchang@stanford.edu
}

\begin{abstract}
Although only $2 \%$ of the genome encodes protein, RNA is transcribed from the majority of the genetic sequence, suggesting a massive degree of cellular functionality is programmed in the noncoding genome. The mammalian genome contains tens of thousands of long noncoding RNAs (IncRNAs), many of which occur at disease-associated loci or are specifically expressed in cancer. Although the vast majority of IncRNAs have no known function, recurring molecular mechanisms for IncRNAs are now being observed in chromatin regulation and cancer pathways and emerging technologies are now providing tools to interrogate IncRNA molecular interactions and determine function of these abundant cellular macromolecules.
\end{abstract}

t has become clear only recently that alterations within the noncoding genome are major contributors to cancer and other human diseases (Maurano et al. 2012). Indeed recurrent somatic noncoding mutations (Melton et al. 2015), epigenetic alterations (Roadmap Epigenomics et al. 2015), or somatic copy number alterations (Beroukhim et al. 2010) are implicated in multiple cancer types. One of the most unexpected findings of the genomics era of biology is that the noncoding genome is the source of extensive transcription of noncoding RNA (Rinn and Chang 2012; Morris and Mattick 2014). Remarkably, several cancer-associated loci contain ultraconserved noncoding RNA sequences suggesting that these transcripts play important roles in cancer pathogenesis (Calin et al. 2007).
The catalog of noncoding genes has grown tremendously over the past few years in large part because of the identification of extensive long noncoding RNA (lncRNA) transcription (Djebali et al. 2012; Harrow et al. 2012; Iyer et al. 2015), arising from active enhancers (Kim et al. 2010), promoters (Seila et al. 2008), and intergenic sequences. Long noncoding RNAs (lncRNAs) are functionally defined as transcripts $>200$ nucleotides in length with no protein coding potential. These transcripts are biochemically similar to messenger RNA (mRNA) and are typically transcribed by RNA polymerase II, polyadenylated, and are frequently spliced, although they often contain fewer exons than coding genes. It is now recognized that lncRNAs are exquisitely regulated and are restricted to specific cell types to a

Editors: Scott A. Armstrong, Steven Henikoff, and Christopher R. Vakoc

Additional Perspectives on Chromatin Deregulation in Cancer available at www.perspectivesinmedicine.org

Copyright (C) 2017 Cold Spring Harbor Laboratory Press; all rights reserved; doi: 10.1101/cshperspect.a026492 Cite this article as Cold Spring Harb Perspect Med 2017;7:a026492 
greater degree than mRNA (Cabili et al. 2011). The catalog of identified lncRNAs now includes tens of thousands of genes and many are uniquely expressed in differentiated tissues or specific cancer types (Iyer et al. 2015). Indeed, the number of IncRNA genes outnumbers protein-coding genes (Derrien et al. 2012) with more than $90 \%$ having no appreciable peptide products (Banfai et al. 2012; Guttman et al. 2013).

Supporting an important functional role for lncRNAs, some lncRNA genes are evolutionarily conserved, although may display limited sequence similarity. Syntenic genomic sites frequently encode evolutionarily conserved, functional lncRNAs (Chodroff et al. 2010; Ulitsky et al. 2011; Hezroni et al. 2015). In a recent report, identification of regions of conserved microhomology within lncRNAs arising from syntenic sites was used to identify a set of 47 orthologs of the Drosophila lncRNA roX in diverse Drosophilid species (Quinn et al. 2016). Despite drastic sequence divergence, roX orthologs maintain regions of conserved secondary structure, retain X-chromosome interactions, and can rescue male lethality in roX-null Drosophila melanogaster.

Despite the rapid pace of discovery in the field, the vast majority of annotated lncRNAs have yet to be functionally characterized. However, several recurring lncRNA molecular mechanisms have been observed, particularly in chromatin biology and gene regulation. The emergence of several technologies over the last few years have expanded investigators abilities to functionally annotate cancer-associated lncRNAs and resulted in an exponential increase in our understanding of these enigmatic molecules (Chu et al. 2015). In this article, we provide an overview of the current state of lncRNA function in cellular molecular mechanisms and review the known roles for lncRNAs in cancer pathophysiology. Portions of this review are abbreviated from recent articles by the investigators (Chu et al. 2015; Schmitt and Chang 2016), and readers are referred to these articles for more in depth treatment of lncRNA as cancer biomarkers or lncRNA-centric technologies, respectively.

\section{LONG NONCODING RNA: EMERGENCE OF A DISTINCT CLASS OF REGULATORY RNA}

In this section we highlight several of the recurring molecular roles of lncRNAs in cellular processes (Fig. 1). Functionality in part begins with lncRNA cellular localization: nuclear lncRNAs are enriched for functionality involving nuclear structure, chromatin interactions, transcriptional regulation, and RNA processing, whereas cytoplasmic lncRNAs can modulate mRNA stability or translation and influence cellular signaling cascades (Batista and Chang 2013). LncRNA transcriptional regulation at the level of chromatin is a widely observed mechanism that can involve activities affecting neighboring intrachromosomal genes in cis or targeting of gene in trans on different chromosomes (Huarte et al. 2010; Huarte 2015; Sahu et al. 2015). LncRNAs are widely known to regulate genes in cis as enhancer-associated RNAs (Orom et al. 2010), through transcription activation or silencing (Huarte et al. 2010; Zhu et al. 2013; Dimitrova et al. 2014; Trimarchi et al. 2014), transcription factor trapping (Sigova et al. 2015), chromatin looping (Wang et al. 2011), and gene methylation (Schmitz et al. 2010) to name just a few mechanisms. LncRNAs also regulate distant genes through modulation of transcription factor recruitment (Hung et al. 2011; Yang et al. 2013b), chromatin modification (Wang and Chang 2011), and serving as a scaffold for assembly of multiple regulatory molecules at single locus (Tsai et al. 2010).

\section{Nuclear Organization}

Deranged nuclear architecture has been a defining feature of cancer cells for $>100$ years since Beale described abnormal nuclear structure in pharyngeal carcinoma cells in the mid-19th century. Nuclear atypia remains an important cytopathologic feature in diagnosing and grading of malignant cells such as in the case of Pap test for cervical neoplasia and in breast carcinoma. Nuclear organization relies heavily on noncoding nuclear RNA (Quinodoz and Guttman 2014). RNase treatment and transcription inhibitors substantially disrupt nuclear organiza- 

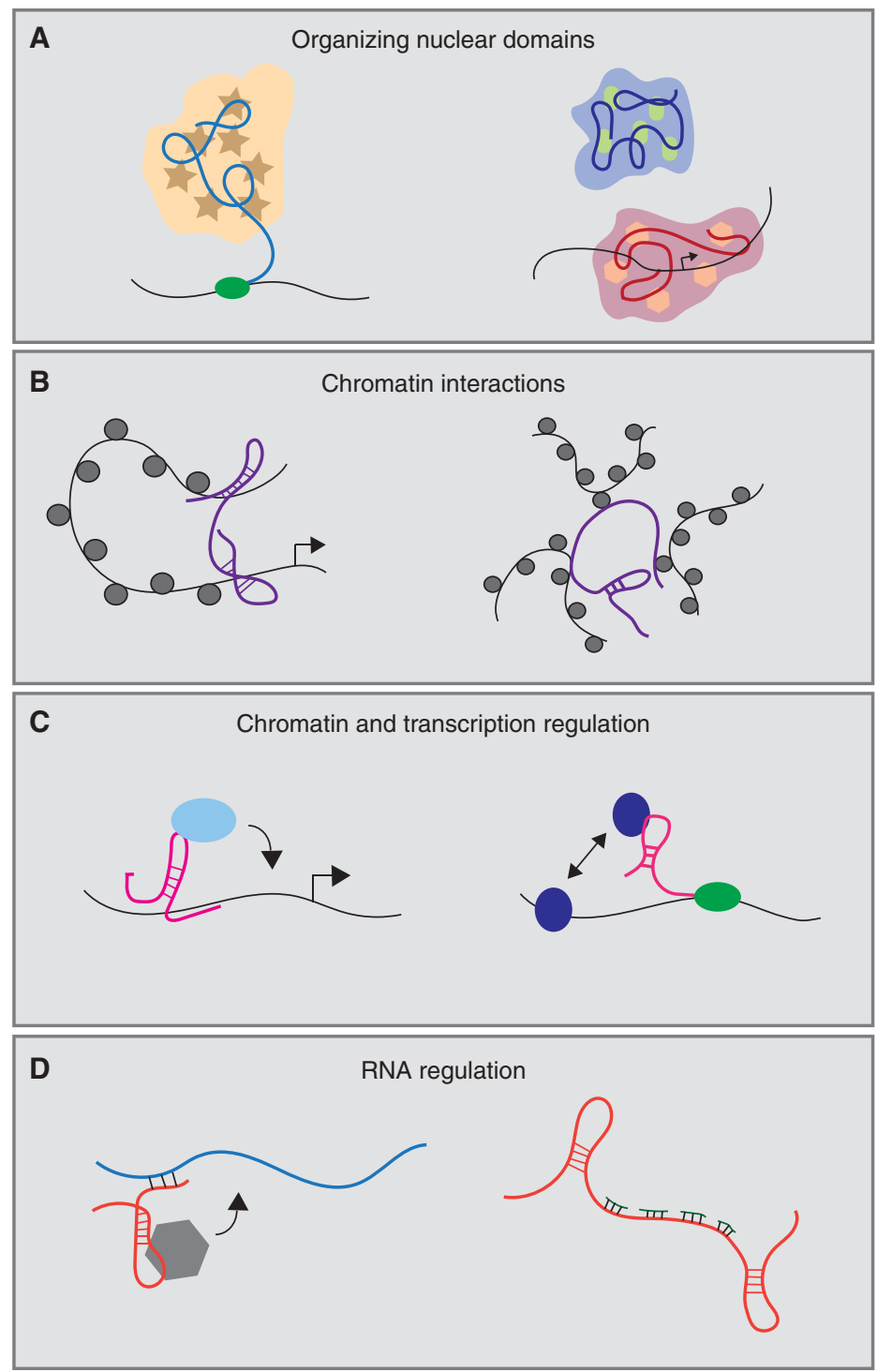

Figure 1. Molecular mechanisms of long noncoding RNAs (lncRNAs). LncRNAs interactions with DNA, RNA, and protein mediate a wide array of cellular functions including $(A)$ nuclear organization, $(B)$ chromatin interactions, $(C)$ chromatin and transcriptional regulation, and $(D)$ RNA regulation.

tion, whereas translation inhibitors did not (Nickerson et al. 1989), pointing to important structural roles for nuclear RNA. It is now clear that nuclear lncRNAs interact with protein, chromatin, and RNA to organize nuclear domains and maintain structure.

Formation of the nuclear paraspeckle, a poorly understood nuclear domain, is dependent on the ncRNA Nuclear enriched abundant transcript 1 (NEAT1). NEAT1 serves as a nidus for formation of the paraspeckle where, on NEAT1 transcription, soluble protein components of the paraspeckle localize to regions of NEAT1 accumulation thus forming the nuclear domain (Clemson et al. 2009; Mao et al. 2011; Shevtsov and Dundr 2011). This domain has been implicated in nuclear retention of A-to-I hyperedited transcripts (Chen and Carmichael 
A.M. Schmitt and H.Y. Chang

2009) and the sequestration of a transcription repressor from its chromatin targets (Imamura et al. 2014). Overexpression of NEAT1 in breast cancer specimens is associated with poor patient survival in which a hypoxic tumor microenvironment induces NEAT1 transcription, increasing paraspeckle formation, enhancing cancer cell survival and stimulating proliferation (Choudhry et al. 2015).

LncRNAs associated with functional nuclear domains can provide anchorage points for the localization of genes undergoing dynamic regulation. The serum response, the activation of which in breast cancer is associated with poor survival (Chang et al. 2004), regulates the localization of dynamically regulated genes between transcriptionally inactive and active nuclear domains. Serum stimulation recruits the demethylase $\mathrm{KDM} 4 \mathrm{C}$ to select promoter regions that are regulated by E2F where it demethylates human Polycomb 2 homolog (Pc2), also known as Chromobox 4 (Yang et al. 2011). Methylated Pc2 interacts with the lncRNA TUG1 in Polycomb bodies, whereas demethylated Pc2 binds MALAT1/NEAT2 localized in interchromatin granules, essentially creating a posttranslation switch for Pc2 interaction with domain defining lncRNAs.

Remarkably, mouse genetic loss of function models of lncRNAs Neat1 and Malat1 have revealed no clear phenotypes in normal animal development (Nakagawa et al. 2011, 2012; Eissmann et al. 2012; Zhang et al. 2012). The contrast of these results with observed in vitro cellular phenotypes suggests that redundancy or compensatory mechanisms may be at work. Yet, Malat1 knockout or depletion by antisense oligonucleotides in a mouse MMTV-PyMT breast cancer model slows tumor growth and inhibits metastasis. Malat1 loss of function promotes cystic differentiation of breast cancer cells and enhances adhesion and inhibits migration (Arun et al. 2016).

\section{Chromatin Interactions}

The three-dimensional organization of chromatin facilitates contacts between distantly spaced intra- or interchromosomal sites allowing for transmittal of regulatory information between distant loci. Chromatin looping facilitates the interaction of the cis interaction of the regulatory lncRNA HOTTIP, which is transcribed from the margin of the HOXA locus, bringing HOTTIP into proximity with other HOXA locus genes and supporting transcription at the locus. HOTTIP, transcribed from the $5^{\prime}$ end of the locus, coordinates transcription along the multigene locus by interacting with WDR5 and recruiting the WDR5/MLL complex to target genes within the locus, increasing $\mathrm{H} 3 \mathrm{~K} 4$ trimethylation and gene transcription (Wang et al. 2011). Similarly, a class of lncRNAs referred to as noncoding RNA-activating recruit Mediator to the site of lncRNA transcription and thereby promote gene transcription of neighboring genes in close proximity because of chromatin looping (Lai et al. 2013).

Distant intra- and interchromosomal chromatin interactions are also mediated by lncRNAs. Enhancer RNAs are a subset of lncRNA transcribed from active enhancer sites. In response to estrogen exposure, enhancer RNAs transcribed from estrogen receptor $\alpha$ $(\mathrm{ER} \alpha)$ bound enhancers facilitate the enhancer-promoter looping induced by estrogen signaling ( $\mathrm{Li}$ et al. 2013). Similarly, the prostate cancer-specific lncRNA PCGEM1 enables chromatin looping between androgen receptor occupied enhancer regions and the promoters of target genes to facilitate their regulation. PCGEM1 bridges the enhancer and promoter regions by binding separately to the androgen receptor (AR) at enhancer sites and pygopus 2 , a H3K4 trimethyl "reader" protein bound to the promoters of AR-regulated genes (Yang et al. 2013b). The X-linked lncRNA Firre interacts with hnRNPU to organize interactions between five chromosomes (Hacisuleyman et al. 2014).

\section{Regulation of Chromatin}

One particularly well-characterized mechanism by which lncRNAs regulate gene expression both in cis and in trans involves interaction with chromatin to facilitate histone modification (Khalil et al. 2009). X-inactive specific transcript (Xist), one of the first functionally anno- 
tated lncRNAs, regulates dosage compensation in female mammals by localizing to the $\mathrm{X}$ chromosome and recruiting multiple factors directly and indirectly, including the polycomb repressive complex 2 (PRC2), to execute X chromosome inactivation (XCI) (Gendrel and Heard 2011; Lee and Bartolomei 2013). That human malignancies frequently have $\mathrm{X}$ aneuploidy suggested an important role for dosage compensation of X-linked genes in preventing malignant transformation (Pageau et al. 2007). Confirming this, female mice with Xist deletion in the hematopoietic compartment develop an aggressive myeloproliferative disorder with full penetrance (Yildirim et al. 2013).

Although Xist coating of the inactive chromosome is required for $\mathrm{X}$ silencing, annotation of Xist interaction domains is a necessary prerequisite for clarifying the role of Xist. To define the genomic interactions of lncRNAs, Chu and colleagues developed chromatin isolation by RNA purification (ChIRP), in which short complementary biotinylated oligonucleotides hybridize to target RNAs and copurify chromatin cross-linked to the target RNA (Chu et al. 2011). Similar methods including capture hybridization analysis of RNA targets (CHART) and RNA antisense purification (RAP) showed that Xist initially binds gene-rich islands on the $\mathrm{X}$ chromosome that are in close three-dimensional proximity, then spreads to gene-poor regions during de novo $\mathrm{X}$ chromosome inactivation ( $\mathrm{Si}$ mon et al. 2011, 2013; Engreitz et al. 2014).

\section{Transcriptional Regulation}

Cancer transcriptional programs are also modulated by lncRNA recruitment to distant promoters and enhancers. ChIRP revealed that Paupar, a central nervous system (CNS) restricted lncRNA located adjacent to Pax6, interacts with numerous promoters to regulate the cell cycle and maintain the dedifferentiated state of neuroblastoma (Vance et al. 2014). NEAT1, a component of nuclear paraspeckles (Clemson et al. 2009), is associated with an increased risk of biochemical progression and metastasis of prostate cancer and is a downstream transcriptional target of $\mathrm{ER} \alpha$ (Chakravarty et al. 2014).
ChIRP revealed that NEAT1 localizes to promoters of genes involved in prostate cancer growth and increased chromatin marks of active transcription at these sites, driving androgenindependent prostate cancer growth. T helper 17 cells are proinflammatory $\mathrm{T}$ cells, and the lncRNA RMRP was shown by ChIRP to coassociate with the key Th17 transcription factor ROR- $\gamma \mathrm{t}$ for inflammatory effector function (Huang et al. 2015). Nascent RNA transcripts in the vicinity of enhancers and promoters can also bind the transcription factor YY1, promoting local accumulation of YY1 in the vicinity of the regulatory sites, supporting the engagement of YY1 with these elements, and driving a positive feedback loop that maintains active transcription (Sigova et al. 2015).

\section{Regulation of RNA Processes}

LncRNA modulation of RNA metabolism is an emerging theme with described roles in the control of mRNA stability, splicing, and translation. Staufen-1 (STAU-1) mediates mRNA decay through interaction with a double-stranded RNA in the $3^{\prime}$ UTR of select mRNAs. However, a subset of STAU-1 regulated mRNAs can only form the requisite double-stranded RNA stem necessary for STAU-1 binding by duplexing with an Alu element of a cytoplasmic lncRNA (Gong and Maquat 2011), thus a lncRNA can confer specificity on the STAU-1-mediated mRNA decay. STAU-1-mRNA interactions are also modulated by terminal differentiation-induced noncoding RNA (TINCR), which drives epidermal differentiation and is down-regulated in poorly differentiated cutaneous squamouscell carcinomas (Kretz et al. 2013). TINCR recruits STAU- 1 to mRNA bearing the 25 nucleotide TINCR Box, somewhat unexpectedly, stabilizing these messages and facilitating the translation of several genes involved in keratinocyte differentiation. DNA damage-induced lncRNA-p21 has been shown to inhibit translation of certain mRNAs such as JUNB and CTNNB1 through a direct RNA-RNA interaction mechanism (Yoon et al. 2012).

Multiple lncRNAs have also been implicated in regulating posttranscriptional mRNA pro- 
cessing. The prostate cancer-specific lncRNA PCA3 (Bussemakers et al. 1999), which is the first lncRNA assayed in an FDA-approved clinical test for prostate cancer, is an intronic lncRNA transcribed antisense to the protein coding gene PRUNE2. Expression of PCA3 in prostate cancer cells leads to formation of a double-stranded RNA heteroduplex with PRUNE2 that is a template for ADAR to perform adenosine-to-ionosine RNA editing and down-regulation of this tumor suppressor (Salameh et al. 2015). In line with prior observations that MALAT1 can regulate alternative splicing through interactions with serine/arginine splicing factors and pre-mRNA, Malat1 binds to nascent strands of pre-mRNA, localizing Malat1 to localize at the proximal chromatin region of transcriptionally active genes (Tripathi et al. 2010; Engreitz et al. 2014).

LncRNAs and pseudogene RNA have also been postulated to act as competing endogenous RNA (ceRNA) or "RNA sponges," interacting with microRNAs in a manner that can sequester these molecules and reduce their regulatory effect on target mRNA (Tay et al. 2014). Transcription of the PTEN pseudogene, PTENP1 and other transcripts, although unable to serve as a template for PTEN translation, nonetheless can increase PTEN protein levels through an RNA-dependent mechanism that involves binding and sequestering PTEN targeting miRNA (Poliseno et al. 2010; Karreth et al. 2011; Tay et al. 2011). Indeed, lncRNAs serving as RNA sponges appear to regulate a diverse array of prostate cancer driver genes (Du et al. 2016). Similar ceRNA mechanisms have been reported for lncRNAs H19 and HULC (Wang et al. 2010; Keniry et al. 2012; Kallen et al. 2013). However, quantitative analyses of miRNA and target mRNA abundance suggest that the ceRNA mechanism could only operate given appropriate stoichiometry between ceRNA, mRNA, and miRNAs. Denzler and colleagues provided compelling quantitative evidence that very high ceRNA copy number thresholds exist for derepression of mRNAs targeted by a miRNA. Their data supports a model in which the number of endogenous miRNA target sites exceeds the number of miRNA copies per cell, resulting in a high fraction of miRNAs already bound to target sites. This model implies that derepression of mRNAs by a ceRNA mechanism requires the number of decoy target sites encoded in a ceRNA to equal or exceed the total number of all miRNA target sites in the cell, which in the case of miR-122 is $\sim 10^{5}$ (Denzler et al. 2014). Thus, quantitative experimental analyses and knockout studies are needed beyond the presence of matching miRNA seed sequences to validate ceRNA mechanisms.

\section{LnCRNA DRIVERS OF CANCER PHENOTYPES}

Cancer cells modulate intracellular signaling networks to proliferate, overcome cytostatic and tumor-suppressor pathways, enhance viability, and promote invasion and metastasis (Hanahan and Weinberg 2000; Hanahan and Weinberg 2011). LncRNAs are key regulators of pathways involving each of the hallmarks of cancer, as described by Hanahan and Weinberg (2000) (Fig. 2). In this section, we review the myriad of cellular activities of lncRNAs in driving classic cancer phenotypes.

\section{Cell Growth and Tumor Suppression}

Normal tissue homeostasis requires a careful balance of the imperative of cellular proliferation and repopulation on the one hand with the need to limit the expansion of deranged cell populations on the other. Multiple lncRNAs are downstream targets of chemokine and hormonal pathways (Xing et al. 2014). In T-cell acute lymphoblastic leukemia, the Notch1 oncogene drives growth in part by inducing the IncRNA LUNAR1 to up-regulate insulin like growth factor 1 receptor expression and signaling (Trimarchi et al. 2014). Estrogen responsive genes depend on enhancer lncRNAs to facilitate local chromatin interactions that promote transcriptional regulation by ER $\alpha$ (Li et al. 2013). Furthermore, androgen signaling in prostate cancer also relies on a number of lncRNAs that are implicated in prostate cancer proliferation that act through direct interactions with the androgen receptor (Yang et al. 2013b; Zhang 


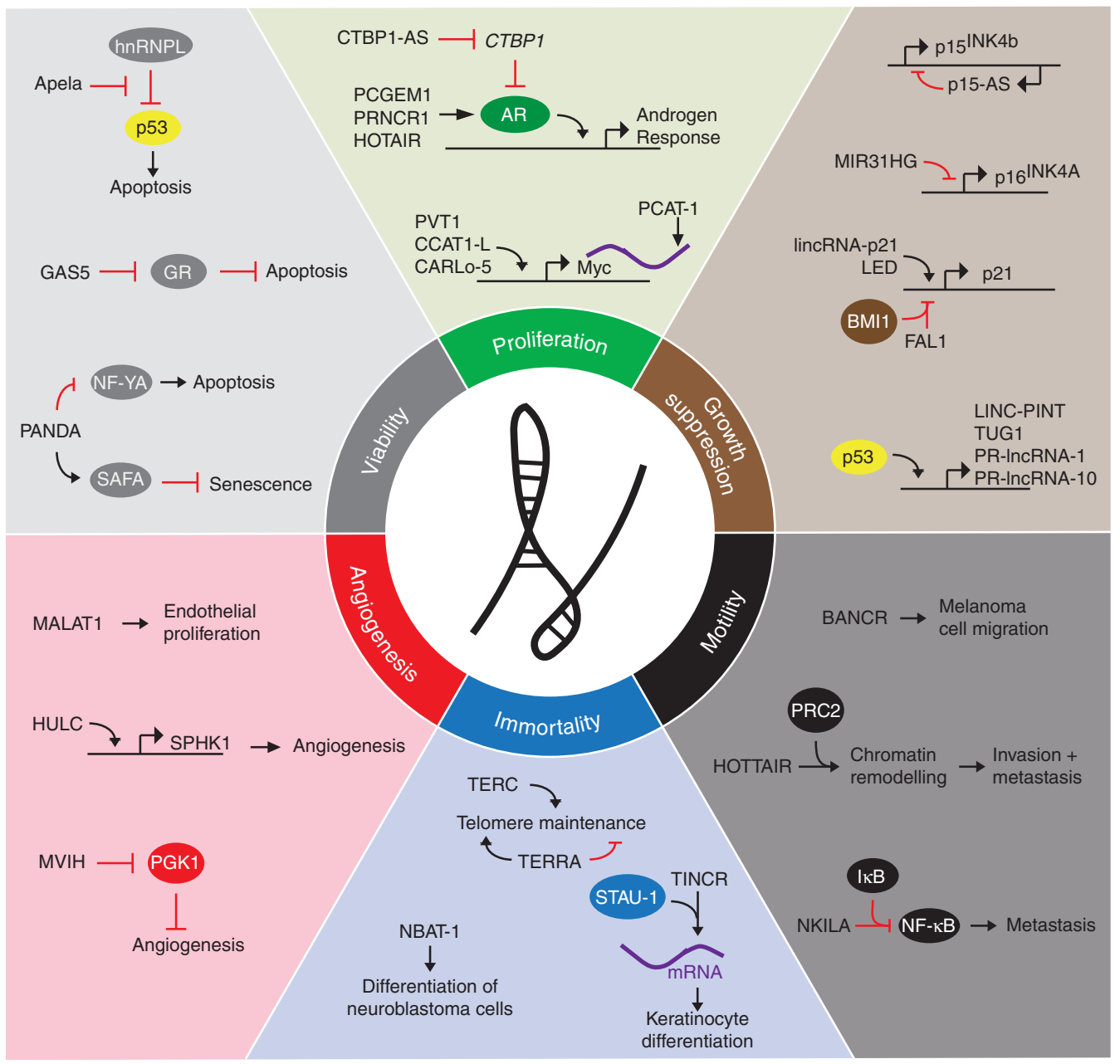

Figure 2. Long noncoding RNAs (lncRNAs) in cancer phenotypes. LncRNAs contribute to each of the six hallmarks of cancer defined by Hanahan and Weinberg. Selected examples of lncRNAs and their molecular partners or genomic targets are shown for proliferation, growth suppression, motility, immortality, angiogenesis, and viability cancer phenotypes. (From Schmitt and Chang 2016; reprinted, with permission, from the authors.)

et al. 2015) or by inhibiting repressors of the androgen receptor (Takayama et al. 2013).

The myc proto-oncogene is the subject of extensive regulation by $\operatorname{lncRNAs}$. Myc transcription is activated in cis by the colon cancer-associated lncRNA CCAT-1, also known as CARLo-5, which promotes long-range interactions between myc and an enhancer element (Kim et al. 2014; Xiang et al. 2014). The prostate specific lncRNA PCGEM1 binds to myc enhancing myc's transcriptional activation of sev- eral genes that regulate metabolic processes in prostate cancer cells (Hung et al. 2014). Myc also targets numerous lncRNAs for transcriptional regulation (Zheng et al. 2014), which can, in turn, regulate cell-cycle progression (Kim et al. 2015).

Amplification of the $8 \mathrm{q} 24$ locus is a wellcharacterized oncogenic event in human malignancies that amplifies MYC copy number. PVT1 is a lncRNA gene that is at the breakpoint of the $t(2: 8)$ translocation in Burkitt lymphoma that 
A.M. Schmitt and H.Y. Chang

brings the human immunoglobulin enhancer to PVT1-MYC locus. In a mouse model of Myc oncogensis, single-copy amplification of $M y c$ alone was insufficient to enhance tumor formation, whereas amplification of a multigene segment encompassing $M y c$ and the lncRNA Pvt1 promoted efficient tumor development (Tseng et al. 2014). Coamplification of Pvt1 and $M y c$ increased myc protein levels, whereas depletion of PVT1 in myc-driven human colon cancer cells impaired proliferation.

Recently several lncRNAs have been found to play an extensive role in modulating tumorsuppressor and growth arrest pathways. The complement of IncRNA transcription is dynamically regulated under differing cell-cycling conditions (Hung et al. 2011) and during senescence (Abdelmohsen et al. 2013). Several tumor-suppressor genes are regulated in cis by their antisense transcripts. For example, the expression of the tumor suppressor TCF21 is activated by its antisense RNA TARID, which recruits the GADD45a to the TCF21 promoter to facilitate demethylation (Arab et al. 2014).

Several IncRNAs regulate the expression of key tumor suppressors from the CDKN2a/ $C D K N 2 b$ locus, which encodes $\mathrm{p} 15^{\mathrm{INK} 4 \mathrm{~b}}$, p $16^{\mathrm{INK} 4 \mathrm{a}}$, and $\mathrm{p} 14^{\mathrm{ARF}}$. The antisense noncoding transcript p15AS induces silencing of $\mathrm{p} 15^{\mathrm{INK} 4 \mathrm{~b}}$ through heterochromatin formation (Yu et al. 2008) and elevated p15AS expression is associated with low $\mathrm{p} 15^{\mathrm{INK} 4 \mathrm{~b}}$ expression in leukemic cells. The lncRNA MIR31HG recruits Polycomb group proteins to the INK4A locus to repress its transcription during normal growth but is sequestered away from the INK4A locus during senescence (Montes et al. 2015).

\section{LncRNAs in the p53 Pathway}

Regulation of the p53 pathway by lncRNAs has been a topic of especially intense interest. The maternally imprinted RNA MEG3 binds to p53 and activates p53-dependent transcription of a subset of p53-regulated genes (Zhou et al.2007). Furthermore, the known complement of p53regulated lncRNAs is growing rapidly pointing to widespread involvement of lncRNAs downstream of p53 activation (Huarte et al. 2010;
Hung et al. 2011; Marin-Bejar et al. 2013; Sanchez et al. 2014; Zhang et al. 2014; Younger et al. 2015). Distant p53 bound enhancer regions generate enhancer RNAs that are required for $\mathrm{p} 53$ 's regulation of multiple genes from a single enhancer site (Melo et al. 2013). Genome wide profiling of p53-regulated enhancer RNAs identified the p53-induced lncRNA LED, which interacts with and activates strong enhancers including a CKDN1A enhancer to support cellcycle arrest by p53. LED is silenced in a subset of p53-wildtype leukemia cells indicating a possible tumor-suppressor role for this lncRNA (Leveille et al. 2015).

LncRNA-p 21, which is induced by DNA damage in a p53-dependent manner, interacts with hnRNA-K to regulate CDKN1A in cis and arrest the cell cycle in a p21-dependent manner (Huarte et al. 2010; Dimitrova et al. 2014). Apela RNA positively regulates DNA damageinduced apoptosis in mouse embryonic stem cells by binding to hnRNPL, inhibiting its ability to sequester p53 away from the mitochondria (Li et al. 2015). The lncRNA FAL-1, located within a region of chromosome 1 with frequent amplification in cancer, recruits the chromatin repressor protein BMI-1 to multiple genes including CDKN1A to promote tumor cell proliferation (Hu et al. 2014a). Additional p53 pathway activities are also regulated by the p53 and DNA damage inducible lncRNA PANDA, which inhibits DNA damage induced apoptosis by binding to the transcription factor NF-YA and blocking its recruitment to proapoptotic genes (Hung et al. 2011). PANDA has also been shown to regulate senescence through and interaction with SAFA and PRC1 (Puvvula et al. 2014).

\section{Enhancing Cellular Survival}

The selective advantage of tumor cells is driven in some cancers by preservation of an undifferentiated tumor cell population. LncRNAs are extensively involved in differentiation circuits and modulation of this functional class of lncRNAs may contribute to the maintenance of cancer stem-cell populations (Flynn and Chang 2014). LncTCF7 recruits the SWI/SNF complex to the TCF7 promoter to activate Wnt 
signaling to maintain liver cancer stem-cell selfrenewal (Wang et al. 2015). Cutaneous squamous-cell carcinoma cells repress the lncRNA TINCR, which is required for keratinocyte differentiation by stabilizing differentiation-associated mRNAs through recruitment of STAU-1 (Kretz et al. 2013). The lncRNA NBAT-1 has also been observed to promote neuronal differentiation in neuroblastoma cells through regulation of the neuron specific transcription factor NRSF/REST, and repression of this lncRNA is associated with high-risk neuroblastoma (Pandey et al. 2014).

The replicative potential of differentiated somatic mammalian cells is typically limited by progressive telomere shortening following replication. However, tumor cells adapt mechanisms to maintain telomeres and effectively obtain immortality. The telomere RNA component (TERC) is a critical subunit of the ribonucleoprotein telomerase complex and encodes the template for the hexanucleotide repeats that compose the telomere sequence (Feng et al. 1995). Single-nucleotide polymorphisms at the TERC locus are associated with telomere lengthening and an increased risk of developing high-grade glioma (Walsh et al. 2014). Meanwhile, Marek's disease virus efficiently induces T-cell lymphomas in chickens by expressing a viral telomerase RNA to promote telomere lengthening (Trapp et al. 2006).

The telomeric repeat containing RNA (TERRA) transcribed from subtelomeric and telomeric DNA sequences exerts both telomerase-dependent and telomerase-independent effects on telomere maintenance (Rippe and Luke 2015). One role for TERRA involves its dynamic regulation during the cell cycle, which promotes the exchange of single-strand DNAbinding protein RPA by POT-1 and thus telomere capping (Flynn et al. 2011). Cancer cells lacking the SWI/SNF component ATRX maintain persistent TERRA loci at telomeres as cells transition from $S$ phase to $G_{2}$. This results in persistent RPA occupancy on the single-stranded telomeric DNA preventing telomerase-dependent telomere lengthening. These cells instead rely on the recombination-dependent alternative pathway of telomere lengthening, which requires ATR, rendering ATRX-deficient cancer cells highly sensitive to ATR inhibitors (Flynn et al. 2015).

Cancer cells that overcome intrinsic checks on growth are yet constantly subjected to conditions of nutrient scarcity and hypoxia and must develop compensatory mechanisms to survive under conditions of stress. Growth arrest specific 5 (Gas5) is induced in cells arrested by nutrient deprivation or withdrawal of growth factors. Gas5 blocks glucocorticoid responsive gene expression by binding to the glucocorticoid receptor's DNA-binding domain and acting as a decoy (Kino et al. 2010; Hudson et al. 2014). This blockade of glucocorticoid receptor decreases expression of the cellular inhibitor of apoptosis 2 (Kino et al. 2010), thereby enhancing apoptosis under stressed conditions in normal cells. Suppression of Gas5 in human breast cancer cells relative to adjacent normal breast tissue has been observed and may support the enhanced viability of breast cancer cells in the nutrient-poor tumor microenvironment (Mourtada-Maarabouni et al. 2009).

\section{Tumor Invasion and Metastasis}

Cancer metastasis was one of the first cancer phenotypes associated with dysregulated lncRNAs. Overexpression of MALAT1 in early stage nonsmall cell lung cancer patients was found to predict a high risk of metastatic progression (Ji et al. 2003). Although MALAT1 loss of function in mouse revealed that it is a nonessential gene in development or for adult normal tissue homeostasis (Nakagawa et al. 2012; Zhang et al. 2012), depletion of MALAT1 in lung carcinoma cells impairs cellular motility in vitro and metastasis in mice (Gutschner et al. 2013), suggesting that MALAT1 overexpression in cancer may drive gain-of-function phenotypes not observed during normal tissue development or homeostasis.

Multiple cancer-associated lncRNAs have been implicated in regulating cancer invasion and metastases (Flockhart et al. 2012; Hu et al. 2014b; Huarte 2015). Overexpression of the HOX-associated lncRNA HOX transcript antisense RNA (HOTAIR) in breast cancer repro- 
grams the chromatin landscape genome-wide via recruitment of PRC2, enforcing a mesenchymal cellular phenotype which promotes breast cancer metastasis (Gupta et al. 2010), and is associated with poor prognosis in other malignancies as well (Kogo et al. 2011). The prostate cancer lncRNA SChLAP1, associated with poor prognosis and metastatic progression (Prensner et al. 2014), promotes prostate cancer invasion and metastasis by disrupting the metastasis suppressing activity of the SWI/SNF complex (Prensner et al. 2013). Transforming growth factor $\beta$ (TGF- $\beta$ ) was found to induce the expression of lncRNA-ATB in hepatocellular carcinoma (HCC) cells, which facilitated the epithelial to mesenchymal transition (EMT), cellular invasion, and organ colonization by HCC cells by two distinct RNA-RNA interactions (Yuan et al. 2014). LncRNA-ATB competitively binds miR-200 to activate the expression of ZEB1 and ZEB2 during EMT, although interactions with IL-11 mRNA enhances Stat3 signaling to promote metastasis. The breast cancer-associated lncRNA BCAR4 connects extracellular CCL22 to noncanonical Gli2 signaling by binding the transcription factors SNIP1 and PNUTS, stimulating cell migration and metastasis (Xing et al. 2014).

Recent identification of metastasis suppressing lncRNAs has opened a new perspective into a link between the tumor microenvironment regulation of $\operatorname{lncRNAs}$ that promote or impair metastasis. The lncRNA LET connects the hypoxia response to the metastasis phenotype. Hypoxia-induced histone deacetylase 3 suppresses the LET promoter, impairing its expression and facilitating nuclear factor 90 accumulation and hypoxia-induced cellular invasion (Yang et al. 2013a). On the other hand, NKILA is a metastasis suppressor lncRNA that is induced by NF- $\mathrm{KB}$ in response to inflammatory signaling. NKILA mediates a negative feedback loop that suppresses NF- $\kappa \mathrm{B}$ signaling by binding the cytoplasmic NF- $\kappa \mathrm{B} / \mathrm{I} \kappa \mathrm{B}$ complex and preventing I $\mathrm{B}$ phosphorylation, NF- $\kappa \mathrm{B}$ release, and nuclear localization (Liu et al. 2015). Downregulation of NKILA expression in human breast cancer is associated to metastatic dissemination of disease and poor prognosis.

\section{FUTURE DIRECTIONS}

LncRNAs occupy a unique niche at the interface of chromatin biology and the regulation of cancer phenotypes. That thousands of these transcripts are differentially expressed in cancer suggests that lncRNAs may play a far greater role in cancer pathways that currently appreciated. However, additional layers of lncRNA regulation are clearly at work that may increase the diversity of lncRNA function far beyond what is currently appreciated. The extensive posttranscriptional modifications of RNA, such as $N^{6}$ methyladenosine, are dynamically regulated in mammalian cells and influence cell fate decisions (Batista et al. 2014; Zhou et al. 2015). Furthermore, RNA structural approaches to evaluating lncRNA functions have revealed that even single-nucleotide polymorphisms can alter local RNA structure at functionally relevant sites involved in miRNA or protein binding (Wan et al. 2014). Application of whole transcriptome RNA structural analyses in cancer may reveal structural consequences of SNPs or somatic mutations within cancer-associated lncRNAs that may alter lncRNA function (Chu et al. 2015; Spitale et al. 2015). Furthermore, the emerging evidence that some putative lncRNAs may encode short, translated open reading frames (Ingolia et al. 2014; Anderson et al. 2015), and that coding RNAs can exert translation-independent functional roles ( $\mathrm{Li}$ et al. 2015), suggests that distinction between mRNA and lncRNA may be less absolute than once thought.

Cataloging the physiologic role of cancerassociated lncRNAs will require an integrated approaches utilizing molecular and cellular characterization as well as animal genetic models (Sauvageau et al. 2013), as recently suggested (Li and Chang 2014). Animal models will be especially critical for elucidating the emerging physiologic roles for noncoding RNA in intercellular signaling, inflammation, angiogenesis, and immune modulation (Bernard et al. 2012; Yuan et al. 2012; Michalik et al. 2014; Lu et al. 2015; Satpathy and Chang 2015) and for identification of therapeutic targets in cancer. Multiple RNA-directed technologies, including antisense oligonucleotides, now provide an op- 
portunity to rationally design targeted drugs to modulate lncRNAs involved in cancer pathophysiology for therapeutic gain (Gaudet et al. 2014; Buller et al. 2015; Meng et al. 2015).

\section{ACKNOWLEDGMENTS}

We apologize to colleagues whose work was not included in this review because of space limitations. This work is supported by the National Institutes of Health (NIH) (R35-CA209919 and R01-ES023168 to H.Y.C.). H.Y.C. is a founder of Epinomics and was a member of the scientific advisory board of RaNa Therapeutics.

\section{REFERENCES}

Abdelmohsen K, Panda A, Kang MJ, Xu J, Selimyan R, Yoon JH, Martindale JL, De S, Wood WH III, Becker KG, et al. 2013. Senescence-associated lncRNAs: senescence-associated long noncoding RNAs. Aging Cell 12: 890-900.

Anderson DM, Anderson KM, Chang CL, Makarewich CA, Nelson BR, McAnally JR, Kasaragod P, Shelton JM, Liou J, Bassel-Duby R, et al. 2015. A micropeptide encoded by a putative long noncoding RNA regulates muscle performance. Cell 160: 595-606.

Arab K, Park YJ, Lindroth AM, Schafer A, Oakes C, Weichenhan D, Lukanova A, Lundin E, Risch A, Meister M, et al. 2014. Long noncoding RNA TARID directs demethylation and activation of the tumor suppressor TCF21 via GADD45A. Mol Cell 55: 604-614.

Arun G, Diermeier S, Akerman M, Chang KC, Wilkinson JE, Hearn S, Kim Y, MacLeod AR, Krainer AR, Norton L, et al. 2016. Differentiation of mammary tumors and reduction in metastasis upon Malat1 lncRNA loss. Genes Dev 30: $34-51$.

Banfai B, Jia H, Khatun J, Wood E, Risk B, Gundling WE Jr, Kundaje A, Gunawardena HP, Yu Y, Xie L, et al. 2012. Long noncoding RNAs are rarely translated in two human cell lines. Genome Res 22: 1646-1657.

Batista PJ, Chang HY. 2013. Long noncoding RNAs: Cellular address codes in development and disease. Cell 152: 1298- 1307 .

Batista PJ, Molinie B, Wang J, Qu K, Zhang J, Li L, Bouley DM, Lujan E, Haddad B, Daneshvar K, et al. 2014. m A RNA modification controls cell fate transition in mammalian embryonic stem cells. Cell Stem Cell 15: 707-719.

Bernard JJ, Cowing-Zitron C, Nakatsuji T, Muehleisen B, Muto J, Borkowski AW, Martinez L, Greidinger EL, Yu BD, Gallo RL. 2012. Ultraviolet radiation damages self noncoding RNA and is detected by TLR3. Nat Med 18: 1286-1290.

Beroukhim R, Mermel CH, Porter D, Wei G, Raychaudhuri S, Donovan J, Barretina J, Boehm JS, Dobson J, Urashima $\mathrm{M}$, et al. 2010. The landscape of somatic copy-number alteration across human cancers. Nature 463: 899-905.
Buller HR, Bethune C, Bhanot S, Gailani D, Monia BP, Raskob GE, Segers A, Verhamme P, Weitz JI, Investigators F-AT. 2015. Factor XI antisense oligonucleotide for prevention of venous thrombosis. N Engl J Med 372: $232-$ 240.

Bussemakers MJ, van Bokhoven A, Verhaegh GW, Smit FP, Karthaus HF, Schalken JA, Debruyne FM, Ru N, Isaacs WB. 1999. DD3: A new prostate-specific gene, highly overexpressed in prostate cancer. Cancer Res 59: 59755979.

Cabili MN, Trapnell C, Goff L, Koziol M, Tazon-Vega B, Regev A, Rinn JL. 2011. Integrative annotation of human large intergenic noncoding RNAs reveals global properties and specific subclasses. Genes Dev 25: 1915-1927.

Calin GA, Liu CG, Ferracin M, Hyslop T, Spizzo R, Sevignani C, Fabbri M, Cimmino A, Lee EJ, Wojcik SE, et al. 2007. Ultraconserved regions encoding ncRNAs are altered in human leukemias and carcinomas. Cancer Cell 12: 215 229.

Chakravarty D, Sboner A, Nair SS, Giannopoulou E, Li R, Hennig S, Mosquera JM, Pauwels J, Park K, Kossai M, et al. 2014. The oestrogen receptor $\alpha$-regulated lncRNA NEAT1 is a critical modulator of prostate cancer. Nat Commun 5: 5383.

Chang HY, Sneddon JB, Alizadeh AA, Sood R, West RB, Montgomery K, Chi JT, van de Rijn M, Botstein D, Brown PO. 2004. Gene expression signature of fibroblast serum response predicts human cancer progression: Similarities between tumors and wounds. PLoS Biol 2: E7.

Chen LL, Carmichael GG. 2009. Altered nuclear retention of mRNAs containing inverted repeats in human embryonic stem cells: Functional role of a nuclear noncoding RNA. Mol Cell 35: 467-478.

Chodroff RA, Goodstadt L, Sirey TM, Oliver PL, Davies KE, Green ED, Molnar Z, Ponting CP. 2010. Long noncoding RNA genes: Conservation of sequence and brain expression among diverse amniotes. Genome Biol 11: R72.

Choudhry H, Albukhari A, Morotti M, Haider S, Moralli D, Smythies J, Schodel J, Green CM, Camps C, Buffa F, et al. 2015. Tumor hypoxia induces nuclear paraspeckle formation through HIF- $2 \alpha$ dependent transcriptional activation of NEAT1 leading to cancer cell survival. Oncogene 34: $4482-4490$.

Chu C, Qu K, Zhong FL, Artandi SE, Chang HY. 2011. Genomic maps of long noncoding RNA occupancy reveal principles of RNA-chromatin interactions. Mol Cell 44: 667-678.

Chu C, Spitale RC, Chang HY. 2015. Technologies to probe functions and mechanisms of long noncoding RNAs. Nat Struct Mol Biol 22: 29-35.

Clemson CM, Hutchinson JN, Sara SA, Ensminger AW, Fox AH, Chess A, Lawrence JB. 2009. An architectural role for a nuclear noncoding RNA: NEAT1 RNA is essential for the structure of paraspeckles. Mol Cell 33: 717-726.

Denzler R, Agarwal V, Stefano J, Bartel DP, Stoffel M. 2014. Assessing the ceRNA hypothesis with quantitative measurements of miRNA and target abundance. Mol Cell 54: 766-776.

Derrien T, Johnson R, Bussotti G, Tanzer A, Djebali S, Tilgner H, Guernec G, Martin D, Merkel A, Knowles DG, et al. 2012. The GENCODE v7 catalog of human 
A.M. Schmitt and H.Y. Chang

long noncoding RNAs: Analysis of their gene structure, evolution, and expression. Genome Res 22: 1775-1789.

Dimitrova N, Zamudio JR, Jong RM, Soukup D, Resnick R, Sarma K, Ward AJ, Raj A, Lee JT, Sharp PA, et al. 2014. LincRNA-p21 activates $p 21$ in cis to promote Polycomb target gene expression and to enforce the $\mathrm{G}_{1} / \mathrm{S}$ checkpoint. Mol Cell 54: 777-790.

Djebali S, Davis CA, Merkel A, Dobin A, Lassmann T, Mortazavi A, Tanzer A, Lagarde J, Lin W, Schlesinger F, et al 2012. Landscape of transcription in human cells. Nature 489: $101-108$.

Du Z, Sun T, Hacisuleyman E, Fei T, Wang X, Brown M, Rinn JL, Lee MG, Chen Y, Kantoff PW, et al. 2016. Integrative analyses reveal a long noncoding RNA-mediated sponge regulatory network in prostate cancer. Nat Commun 7: 10982.

Eissmann M, Gutschner T, Hammerle M, Gunther S, Caudron-Herger M, Gross M, Schirmacher P, Rippe K, Braun T, Zornig M, et al. 2012. Loss of the abundant nuclear noncoding RNA MALAT1 is compatible with life and development. RNA Biol 9: 1076-1087.

Engreitz JM, Sirokman K, McDonel P, Shishkin AA, Surka C, Russell P, Grossman SR, Chow AY, Guttman M, Lander ES. 2014. RNA-RNA interactions enable specific targeting of noncoding RNAs to nascent Pre-mRNAs and chromatin sites. Cell 159: 188-199.

Feng J, Funk WD, Wang SS, Weinrich SL, Avilion AA, Chiu CP, Adams RR, Chang E, Allsopp RC, Yu J, et al. 1995. The RNA component of human telomerase. Science 269: 1236-1241.

Flockhart RJ, Webster DE, Qu K, Mascarenhas N, Kovalski J, Kretz M, Khavari PA. 2012. BRAFV600E remodels the melanocyte transcriptome and induces BANCR to regulate melanoma cell migration. Genome Res 22: $1006-$ 1014.

Flynn RA, Chang HY. 2014. Long noncoding RNAs in cellfate programming and reprogramming. Cell Stem Cell 14: $752-761$.

Flynn RL, Centore RC, O’Sullivan RJ, Rai R, Tse A, Songyang Z, Chang S, Karlseder J, Zou L. 2011. TERRA and hnRNPA1 orchestrate an RPA-to-POT1 switch on telomeric single-stranded DNA. Nature 471: 532-536.

Flynn RL, Cox KE, Jeitany M, Wakimoto H, Bryll AR, Ganem NJ, Bersani F, Pineda JR, Suva ML, Benes CH, et al. 2015. Alternative lengthening of telomeres renders cancer cells hypersensitive to ATR inhibitors. Science 347: $273-$ 277.

Gaudet D, Brisson D, Tremblay K, Alexander VJ, Singleton W, Hughes SG, Geary RS, Baker BF, Graham MJ, Crooke RM, et al. 2014. Targeting APOC3 in the familial chylomicronemia syndrome. N Engl J Med 371: 2200-2206.

Gendrel AV, Heard E. 2011. Fifty years of X-inactivation research. Development 138: 5049-5055.

Gong C, Maquat LE. 2011. IncRNAs transactivate STAU1mediated mRNA decay by duplexing with $3^{\prime}$ UTRs via Alu elements. Nature 470: 284-288.

Gupta RA, Shah N, Wang KC, Kim J, Horlings HM, Wong DJ, Tsai MC, Hung T, Argani P, Rinn JL, et al. 2010. Long noncoding RNA HOTAIR reprograms chromatin state to promote cancer metastasis. Nature 464: 1071-1076.
Gutschner T, Hammerle M, Eissmann M, Hsu J, Kim Y, Hung G, Revenko A, Arun G, Stentrup M, Gross M, et al. 2013. The noncoding RNA MALAT1 is a critical regulator of the metastasis phenotype of lung cancer cells. Cancer Res 73: 1180-1189.

Guttman M, Russell P, Ingolia NT, Weissman JS, Lander ES. 2013. Ribosome profiling provides evidence that large noncoding RNAs do not encode proteins. Cell 154: $240-251$.

Hacisuleyman E, Goff LA, Trapnell C, Williams A, HenaoMejia J, Sun L, McClanahan P, Hendrickson DG, Sauvageau M, Kelley DR, et al. 2014. Topological organization of multichromosomal regions by the long intergenic noncoding RNA Firre. Nat Struct Mol Biol 21: 198-206.

Hanahan D, Weinberg RA. 2000. The hallmarks of cancer. Cell 100: $57-70$.

Hanahan D, Weinberg RA. 2011. Hallmarks of cancer: The next generation. Cell 144: 646-674.

Harrow J, Frankish A, Gonzalez JM, Tapanari E, Diekhans M, Kokocinski F, Aken BL, Barrell D, Zadissa A, Searle S, et al. 2012. GENCODE: The reference human genome annotation for The ENCODE Project. Genome Res 22: $1760-1774$.

Hezroni H, Koppstein D, Schwartz MG, Avrutin A, Bartel DP, Ulitsky I. 2015. Principles of long noncoding RNA evolution derived from direct comparison of transcriptomes in 17 species. Cell Rep 11: 1110-1122.

Hu X, Feng Y, Zhang D, Zhao SD, Hu Z, Greshock J, Zhang Y, Yang L, Zhong X, Wang LP, et al. 2014a. A functional genomic approach identifies FAL1 as an oncogenic long noncoding RNA that associates with BMI1 and represses p21 expression in cancer. Cancer Cell 26: 344-357.

Hu Y, Wang J, Qian J, Kong X, Tang J, Wang Y, Chen H, Hong J, Zou W, Chen Y, et al. 2014b. Long noncoding RNA GAPLINC regulates CD44-dependent cell invasiveness and associates with poor prognosis of gastric cancer. Cancer Res 74: 6890-6902.

Huang W, Thomas B, Flynn RA, Gavzy SJ, Wu L, Kim SV, Hall JA, Miraldi ER, Ng CP, Rigo FW, et al. 2015. DDX5 and its associated lncRNA Rmrp modulate TH17 cell effector functions. Nature 528: 517-522.

Huarte M. 2015. The emerging role of lncRNAs in cancer. Nat Med 21: 1253-1261.

Huarte M, Guttman M, Feldser D, Garber M, Koziol MJ, Kenzelmann-Broz D, Khalil AM, Zuk O, Amit I, Rabani $\mathrm{M}$, et al. 2010. A large intergenic noncoding RNA induced by p53 mediates global gene repression in the p53 response. Cell 142: 409-419.

Hudson WH, Pickard MR, de Vera IM, Kuiper EG, Mourtada-Maarabouni M, Conn GL, Kojetin DJ, Williams GT, Ortlund EA. 2014. Conserved sequence-specific lincRNA-steroid receptor interactions drive transcriptional repression and direct cell fate. Nat Commun 5: 5395.

Hung T, Wang Y, Lin MF, Koegel AK, Kotake Y, Grant GD, Horlings HM, Shah N, Umbricht C, Wang P, et al. 2011. Extensive and coordinated transcription of noncoding RNAs within cell-cycle promoters. Nat Genet 43: 621629.

Hung CL, Wang LY, Yu YL, Chen HW, Srivastava S, Petrovics G, Kung HJ. 2014. A long noncoding RNA connects 
Long Noncoding RNAs in Cancer and Chromatin Biology

c-Myc to tumor metabolism. Proc Natl Acad Sci 111: 18697-18702.

Imamura K, Imamachi N, Akizuki G, Kumakura M, Kawaguchi A, Nagata K, Kato A, Kawaguchi Y, Sato H, Yoneda $\mathrm{M}$, et al. 2014. Long noncoding RNA NEAT1-dependent SFPQ relocation from promoter region to paraspeckle mediates IL8 expression upon immune stimuli. Mol Cell 53: 393-406.

Ingolia NT, Brar GA, Stern-Ginossar N, Harris MS, Talhouarne GJ, Jackson SE, Wills MR, Weissman JS. 2014. Ribosome profiling reveals pervasive translation outside of annotated protein-coding genes. Cell Rep 8: 13651379.

Iyer MK, Niknafs YS, Malik R, Singhal U, Sahu A, Hosono Y, Barrette TR, Prensner JR, Evans JR, Zhao S, et al. 2015. The landscape of long noncoding RNAs in the human transcriptome. Nat Genet 47: 199-208.

Ji P, Diederichs S, Wang W, Boing S, Metzger R, Schneider PM, Tidow N, Brandt B, Buerger H, Bulk E, et al. 2003. MALAT-1, a novel noncoding RNA, and thymosin $\beta 4$ predict metastasis and survival in early-stage nonsmall cell lung cancer. Oncogene 22: 8031-8041.

Kallen AN, Zhou XB, Xu J, Qiao C, Ma J, Yan L, Lu L, Liu C, Yi JS, Zhang H, et al. 2013. The imprinted H19 lncRNA antagonizes let-7 microRNAs. Mol Cell 52: 101-112.

Karreth FA, Tay Y, Perna D, Ala U, Tan SM, Rust AG, DeNicola G, Webster KA, Weiss D, Perez-Mancera PA, et al 2011. In vivo identification of tumor-suppressive PTEN ceRNAs in an oncogenic BRAF-induced mouse model of melanoma. Cell 147: 382-395.

Keniry A, Oxley D, Monnier P, Kyba M, Dandolo L, Smits G, Reik W. 2012. The H19 lincRNA is a developmental reservoir of miR-675 that suppresses growth and Igf1r. Nat Cell Biol 14: 659-665.

Khalil AM, Guttman M, Huarte M, Garber M, Raj A, Rivea Morales D, Thomas K, Presser A, Bernstein BE, van Oudenaarden A, et al. 2009. Many human large intergenic noncoding RNAs associate with chromatin-modifying complexes and affect gene expression. Proc Natl Acad Sci 106: 11667-11672.

Kim TK, Hemberg M, Gray JM, Costa AM, Bear DM, Wu J, Harmin DA, Laptewicz M, Barbara-Haley K, Kuersten S, et al. 2010. Widespread transcription at neuronal activity-regulated enhancers. Nature 465: 182-187.

Kim T, Cui R, Jeon YJ, Lee JH, Lee JH, Sim H, Park JK, Fadda P, Tili E, Nakanishi H, et al. 2014. Long-range interaction and correlation between MYC enhancer and oncogenic long noncoding RNA CARLo-5. Proc Natl Acad Sci 111: 4173-4178.

Kim T, Cui R, Jeon YJ, Fadda P, Alder H, Croce CM. 2015. MYC-repressed long noncoding RNAs antagonize MYCinduced cell proliferation and cell cycle progression. Oncotarget 6: 18780-18789.

Kino T, Hurt DE, Ichijo T, Nader N, Chrousos GP. 2010. Noncoding RNA gas5 is a growth arrest- and starvation-associated repressor of the glucocorticoid receptor. Sci Signal 3: ra8.

Kogo R, Shimamura T, Mimori K, Kawahara K, Imoto S, Sudo T, Tanaka F, Shibata K, Suzuki A, Komune S, et al. 2011. Long noncoding RNA HOTAIR regulates polycomb-dependent chromatin modification and is associ- ated with poor prognosis in colorectal cancers. Cancer Res 71: 6320-6326.

Kretz M, Siprashvili Z, Chu C, Webster DE, Zehnder A, Qu K, Lee CS, Flockhart RJ, Groff AF, Chow J, et al. 2013. Control of somatic tissue differentiation by the long noncoding RNA TINCR. Nature 493: 231-235.

Lai F, Orom UA, Cesaroni M, Beringer M, Taatjes DJ, Blobel GA, Shiekhattar R. 2013. Activating RNAs associate with Mediator to enhance chromatin architecture and transcription. Nature 494: 497-501.

Lee JT, Bartolomei MS. 2013. X-inactivation, imprinting, and long noncoding RNAs in health and disease. Cell 152: $1308-1323$.

Leveille N, Melo CA, Rooijers K, Diaz-Lagares A, Melo SA, Korkmaz G, Lopes R, Akbari Moqadam F, Maia AR, Wijchers PJ, et al. 2015. Genome-wide profiling of p53-regulated enhancer RNAs uncovers a subset of enhancers controlled by a lncRNA. Nat Commun 6: 6520.

Li L, Chang HY. 2014. Physiological roles of long noncoding RNAs: Insight from knockout mice. Trends Cell Biol 24: 594-602.

Li W, Notani D, Ma Q, Tanasa B, Nunez E, Chen AY, Merkurjev D, Zhang J, Ohgi K, Song X, et al. 2013. Functional roles of enhancer RNAs for oestrogen-dependent transcriptional activation. Nature 498: 516-520.

Li M, Gou H, Tripathi BK, Huang J, Jiang S, Dubois W, Waybright T, Lei M, Shi J, Zhou M, et al. 2015. An Apela RNA-containing negative feedback loop regulates p53mediated apoptosis in embryonic stem cells. Cell Stem Cell 16: 669-683.

Liu B, Sun L, Liu Q, Gong C, Yao Y, Lv X, Lin L, Yao H, Su F, Li D, et al. 2015. A cytoplasmic NF-кB interacting long noncoding RNA blocks IкB phosphorylation and suppresses breast cancer metastasis. Cancer Cell 27:370-381.

Lu Z, Xiao Z, Liu F, Cui M, Li W, Yang Z, Li J, Ye L, Zhang X. 2015. Long noncoding RNA HULC promotes tumor angiogenesis in liver cancer by up-regulating sphingosine kinase 1 (SPHK1). Oncotarget 7: 241-254.

Mao YS, Sunwoo H, Zhang B, Spector DL. 2011. Direct visualization of the cotranscriptional assembly of a nuclear body by noncoding RNAs. Nat Cell Biol 13: 95-101.

Marin-Bejar O, Marchese FP, Athie A, Sanchez Y, Gonzalez J, Segura V, Huang L, Moreno I, Navarro A, Monzo M, et al. 2013. Pint lincRNA connects the p53 pathway with epigenetic silencing by the Polycomb repressive complex 2. Genome Biol 14: R104.

Maurano MT, Humbert R, Rynes E, Thurman RE, Haugen E, Wang H, Reynolds AP, Sandstrom R, Qu H, Brody J, et al. 2012. Systematic localization of common disease-associated variation in regulatory DNA. Science 337: $1190-$ 1195.

Melo CA, Drost J, Wijchers PJ, van de Werken H, de Wit E, Oude Vrielink JA, Elkon R, Melo SA, Leveille N, Kalluri R, et al. 2013. eRNAs are required for p53-dependent enhancer activity and gene transcription. Mol Cell 49: 524535.

Melton C, Reuter JA, Spacek DV, Snyder M. 2015. Recurrent somatic mutations in regulatory regions of human cancer genomes. Nat Genet 47: 710-716. 
A.M. Schmitt and H.Y. Chang

Meng L, Ward AJ, Chun S, Bennett CF, Beaudet AL, Rigo F. 2015. Towards a therapy for Angelman syndrome by targeting a long noncoding RNA. Nature 518: 409-412.

Michalik KM, You X, Manavski Y, Doddaballapur A, Zornig M, Braun T, John D, Ponomareva Y, Chen W, Uchida S, et al. 2014. Long noncoding RNA MALAT1 regulates endothelial cell function and vessel growth. Circ Res 114: 1389-1397.

Montes M, Nielsen MM, Maglieri G, Jacobsen A, Hojfeldt J, Agrawal-Singh S, Hansen K, Helin K, van de Werken HJ, Pedersen JS, et al. 2015. The lncRNA MIR31HG regulates p16(INK4A) expression to modulate senescence. Nat Commun 6: 6967.

Morris KV, Mattick JS. 2014. The rise of regulatory RNA. Nat Rev Genet 15: 423-437.

Mourtada-Maarabouni M, Pickard MR, Hedge VL, Farzaneh F, Williams GT. 2009. GAS5, a nonprotein-coding RNA, controls apoptosis and is downregulated in breast cancer. Oncogene 28: 195-208.

Nakagawa S, Naganuma T, Shioi G, Hirose T. 2011. Paraspeckles are subpopulation-specific nuclear bodies that are not essential in mice. J Cell Biol 193: 31-39.

Nakagawa S, Ip JY, Shioi G, Tripathi V, Zong X, Hirose T, Prasanth KV. 2012. Malat1 is not an essential component of nuclear speckles in mice. RNA 18: 1487-1499.

Nickerson JA, Krochmalnic G, Wan KM, Penman S. 1989. Chromatin architecture and nuclear RNA. Proc Natl Acad Sci 86: 177-181.

Orom UA, Derrien T, Beringer M, Gumireddy K, Gardini A Bussotti G, Lai F, Zytnicki M, Notredame C, Huang Q, et al. 2010. Long noncoding RNAs with enhancer-like function in human cells. Cell 143: 46-58.

Pageau GJ, Hall LL, Ganesan S, Livingston DM, Lawrence JB. 2007. The disappearing Barr body in breast and ovarian cancers. Nat Rev Cancer 7: 628-633.

Pandey GK, Mitra S, Subhash S, Hertwig F, Kanduri M, Mishra K, Fransson S, Ganeshram A, Mondal T, Bandaru $\mathrm{S}$, et al. 2014. The risk-associated long noncoding RNA NBAT-1 controls neuroblastoma progression by regulating cell proliferation and neuronal differentiation. Cancer Cell 26: 722-737.

Poliseno L, Salmena L, Zhang J, Carver B, Haveman WJ, Pandolfi PP. 2010. A coding-independent function of gene and pseudogene mRNAs regulates tumour biology. Nature 465: 1033-1038.

Prensner JR, Iyer MK, Sahu A, Asangani IA, Cao Q, Patel L, Vergara IA, Davicioni E, Erho N, Ghadessi M, et al. 2013. The long noncoding RNA SChLAP1 promotes aggressive prostate cancer and antagonizes the SWI/SNF complex. Nat Genet 45: 1392-1398.

Prensner JR, Zhao S, Erho N, Schipper M, Iyer MK, Dhanasekaran SM, Magi-Galluzzi C, Mehra R, Sahu A, Siddiqui J, et al. 2014. RNA biomarkers associated with metastatic progression in prostate cancer: A multi-institutional high-throughput analysis of SChLAP1. Lancet Oncol 15: 1469-1480.

Puvvula PK, Desetty RD, Pineau P, Marchio A, Moon A, Dejean A, Bischof O. 2014. Long noncoding RNA PANDA and scaffold-attachment-factor SAFA control senescence entry and exit. Nat Commun 5: 5323.
Quinn JJ, Zhang QC, Georgiev P, Ilik IA, Akhtar A, Chang HY. 2016. Rapid evolutionary turnover underlies conserved lncRNA-genome interactions. Genes Dev 30: 191-207.

Quinodoz S, Guttman M. 2014. Long noncoding RNAs: An emerging link between gene regulation and nuclear organization. Trends Cell Biol 24: 651-663.

Rinn JL, Chang HY. 2012. Genome regulation by long noncoding RNAs. Annu Rev Biochem 81: 145-166.

Rippe K, Luke B. 2015. TERRA and the state of the telomere. Nat Struct Mol Biol 22: 853-858.

Roadmap Epigenomics C, Kundaje A, Meuleman W, Ernst J, Bilenky M, Yen A, Heravi-Moussavi A, Kheradpour P, Zhang Z, Wang J, et al. 2015. Integrative analysis of 111 reference human epigenomes. Nature 518: 317-330.

Sahu A, Singhal U, Chinnaiyan AM. 2015. Long noncoding RNAs in cancer: From function to translation. Trends Cancer 1: 93-109.

Salameh A, Lee AK, Cardo-Vila M, Nunes DN, Efstathiou E, Staquicini FI, Dobroff AS, Marchio S, Navone NM, Hosoya $\mathrm{H}$, et al. 2015. PRUNE2 is a human prostate cancer suppressor regulated by the intronic long noncoding RNA PCA3. Proc Natl Acad Sci 112: 8403-8408.

Sanchez Y, Segura V, Marin-Bejar O, Athie A, Marchese FP, Gonzalez J, Bujanda L, Guo S, Matheu A, Huarte M. 2014. Genome-wide analysis of the human p53 transcriptional network unveils an lncRNA tumour suppressor signature. Nat Commun 5: 5812.

Satpathy AT, Chang HY. 2015. Long noncoding RNA in hematopoiesis and immunity. Immunity 42: 792-804.

Sauvageau M, Goff LA, Lodato S, Bonev B, Groff AF, Gerhardinger C, Sanchez-Gomez DB, Hacisuleyman E, Li E, Spence M, et al. 2013. Multiple knockout mouse models reveal lincRNAs are required for life and brain development. eLife 2: e01749.

Schmitt AM, Chang HY. 2016. Long noncoding RNAs in cancer pathways. Cancer Cell 29: 452-463.

Schmitz KM, Mayer C, Postepska A, Grummt I. 2010. Interaction of noncoding RNA with the rDNA promoter mediates recruitment of DNMT3b and silencing of rRNA genes. Genes Dev 24: 2264-2269.

Seila AC, Calabrese JM, Levine SS, Yeo GW, Rahl PB, Flynn RA, Young RA, Sharp PA. 2008. Divergent transcription from active promoters. Science 322: 1849-1851.

Shevtsov SP, Dundr M. 2011. Nucleation of nuclear bodies by RNA. Nat Cell Biol 13: 167-173.

Sigova AA, Abraham BJ, Ji X, Molinie B, Hannett NM, Guo YE, Jangi M, Giallourakis CC, Sharp PA, Young RA. 2015. Transcription factor trapping by RNA in gene regulatory elements. Science 350: 978-981.

Simon MD, Wang CI, Kharchenko PV, West JA, Chapman BA, Alekseyenko AA, Borowsky ML, Kuroda MI, Kingston RE. 2011. The genomic binding sites of a noncoding RNA. Proc Natl Acad Sci 108: 20497-20502.

Simon MD, Pinter SF, Fang R, Sarma K, Rutenberg-Schoenberg M, Bowman SK, Kesner BA, Maier VK, Kingston RE Lee JT. 2013. High-resolution Xist binding maps reveal two-step spreading during $\mathrm{X}$-chromosome inactivation. Nature 504: 465-469.

Spitale RC, Flynn RA, Zhang QC, Crisalli P, Lee B, Jung JW, Kuchelmeister HY, Batista PJ, Torre EA, Kool ET, et al. 
2015. Structural imprints in vivo decode RNA regulatory mechanisms. Nature 519: 486-490.

Takayama K, Horie-Inoue K, Katayama S, Suzuki T, Tsutsumi S, Ikeda K, Urano T, Fujimura T, Takagi K, Takahashi S, et al. 2013. Androgen-responsive long noncoding RNA CTBP1-AS promotes prostate cancer. $E M B O J$ 32: $1665-1680$.

Tay Y, Kats L, Salmena L, Weiss D, Tan SM, Ala U, Karreth F, Poliseno L, Provero P, Di Cunto F, et al. 2011. Codingindependent regulation of the tumor suppressor PTEN by competing endogenous mRNAs. Cell 147: 344-357.

Tay Y, Rinn J, Pandolfi PP. 2014. The multilayered complexity of ceRNA crosstalk and competition. Nature 505: 344-352.

Trapp S, Parcells MS, Kamil JP, Schumacher D, Tischer BK, Kumar PM, Nair VK, Osterrieder N. 2006. A virus-encoded telomerase RNA promotes malignant $\mathrm{T}$ cell lymphomagenesis. J Exp Med 203: 1307-1317.

Trimarchi T, Bilal E, Ntziachristos P, Fabbri G, Dalla-Favera R, Tsirigos A, Aifantis I. 2014. Genome-wide mapping and characterization of Notch-regulated long noncoding RNAs in acute leukemia. Cell 158: 593-606.

Tripathi V, Ellis JD, Shen Z, Song DY, Pan Q, Watt AT, Freier SM, Bennett CF, Sharma A, Bubulya PA, et al. 2010. The nuclear-retained noncoding RNA MALAT1 regulates alternative splicing by modulating SR splicing factor phosphorylation. Mol Cell 39: 925-938.

Tsai MC, Manor O, Wan Y, Mosammaparast N, Wang JK, Lan F, Shi Y, Segal E, Chang HY. 2010. Long noncoding RNA as modular scaffold of histone modification complexes. Science 329: 689-693.

Tseng YY, Moriarity BS, Gong W, Akiyama R, Tiwari A, Kawakami H, Ronning P, Reuland B, Guenther K, Beadnell TC, et al. 2014. PVT1 dependence in cancer with MYC copy-number increase. Nature 512: 82-86.

Ulitsky I, Shkumatava A, Jan CH, Sive H, Bartel DP. 2011. Conserved function of lincRNAs in vertebrate embryonic development despite rapid sequence evolution. Cell 147: 1537-1550.

Vance KW, Sansom SN, Lee S, Chalei V, Kong L, Cooper SE, Oliver PL, Ponting CP. 2014. The long noncoding RNA Paupar regulates the expression of both local and distal genes. EMBO J 33: 296-311.

Walsh KM, Codd V, Smirnov IV, Rice T, Decker PA, Hansen HM, Kollmeyer T, Kosel ML, Molinaro AM, McCoy LS, et al. 2014. Variants near TERT and TERC influencing telomere length are associated with high-grade glioma risk. Nat Genet 46: 731-735.

Wan Y, Qu K, Zhang QC, Flynn RA, Manor O, Ouyang Z, Zhang J, Spitale RC, Snyder MP, Segal E, et al. 2014. Landscape and variation of RNA secondary structure across the human transcriptome. Nature 505: 706-709.

Wang KC, Chang HY. 2011. Molecular mechanisms of long noncoding RNAs. Mol Cell 43: 904-914.

Wang J, Liu X, Wu H, Ni P, Gu Z, Qiao Y, Chen N, Sun F, Fan Q. 2010. CREB up-regulates long noncoding RNA HULC expression through interaction with microRNA372 in liver cancer. Nucleic Acids Res 38: 5366-5383.

Wang KC, Yang YW, Liu B, Sanyal A, Corces-Zimmerman R, Chen Y, Lajoie BR, Protacio A, Flynn RA, Gupta RA, et al. 2011. A long noncoding RNA maintains active chromatin to coordinate homeotic gene expression. Nature 472: $120-124$.

Wang Y, He L, Du Y, Zhu P, Huang G, Luo J, Yan X, Ye B, Li C, Xia P, et al. 2015. The long noncoding RNA lncTCF7 promotes self-renewal of human liver cancer stem cells through activation of Wnt signaling. Cell Stem Cell 16: 413-425.

Xiang JF, Yin QF, Chen T, Zhang Y, Zhang XO, Wu Z, Zhang S, Wang HB, Ge J, Lu X, et al. 2014. Human colorectal cancer-specific CCAT1-L lncRNA regulates long-range chromatin interactions at the MYC locus. Cell Res 24: $513-531$.

Xing Z, Lin A, Li C, Liang K, Wang S, Liu Y, Park PK, Qin L, Wei Y, Hawke DH, et al. 2014. lncRNA directs cooperative epigenetic regulation downstream of chemokine signals. Cell 159: 1110-1125.

Yang L, Lin C, Liu W, Zhang J, Ohgi KA, Grinstein JD, Dorrestein PC, Rosenfeld MG. 2011. ncRNA- and Pc2 methylation-dependent gene relocation between nuclear structures mediates gene activation programs. Cell 147: $773-788$.

Yang F, Huo XS, Yuan SX, Zhang L, Zhou WP, Wang F, Sun SH. 2013a. Repression of the long noncoding RNA-LET by histone deacetylase 3 contributes to hypoxia-mediated metastasis. Mol Cell 49: 1083-1096.

Yang L, Lin C, Jin C, Yang JC, Tanasa B, Li W, Merkurjev D, Ohgi KA, Meng D, Zhang J, et al. 2013b. IncRNA-dependent mechanisms of androgen-receptor-regulated gene activation programs. Nature 500: 598-602.

Yildirim E, Kirby JE, Brown DE, Mercier FE, Sadreyev RI, Scadden DT, Lee JT. 2013. Xist RNA is a potent suppressor of hematologic cancer in mice. Cell 152: 727-742.

Yoon JH, Abdelmohsen K, Srikantan S, Yang X, Martindale JL, De S, Huarte M, Zhan M, Becker KG, Gorospe M. 2012. LincRNA-p21 suppresses target mRNA translation. Mol Cell 47: 648-655.

Younger ST, Kenzelmann-Broz D, Jung H, Attardi LD, Rinn JL. 2015. Integrative genomic analysis reveals widespread enhancer regulation by $\mathrm{p} 53$ in response to DNA damage. Nucleic Acids Res 43: 4447-4462.

Yu W, Gius D, Onyango P, Muldoon-Jacobs K, Karp J, Feinberg AP, Cui H. 2008. Epigenetic silencing of tumour suppressor gene p15 by its antisense RNA. Nature 451: 202-206.

Yuan SX, Yang F, Yang Y, Tao QF, Zhang J, Huang G, Yang Y, Wang RY, Yang S, Huo XS, et al. 2012. Long noncoding RNA associated with microvascular invasion in hepatocellular carcinoma promotes angiogenesis and serves as a predictor for hepatocellular carcinoma patients' poor recurrence-free survival after hepatectomy. Hepatology 56: 2231-2241.

Yuan JH, Yang F, Wang F, Ma JZ, Guo YJ, Tao QF, Liu F, Pan W, Wang TT, Zhou CC, et al. 2014. A long noncoding RNA activated by TGF- $\beta$ promotes the invasion-metastasis cascade in hepatocellular carcinoma. Cancer Cell 25: $666-681$.

Zhang B, Arun G, Mao YS, Lazar Z, Hung G, Bhattacharjee G, Xiao X, Booth CJ, Wu J, Zhang C, et al. 2012. The lncRNA Malat1 is dispensable for mouse development but its transcription plays a cis-regulatory role in the adult. Cell Rep 2: 111-123. 
A.M. Schmitt and H.Y. Chang

Zhang EB, Yin DD, Sun M, Kong R, Liu XH, You LH, Han L, Xia R, Wang KM, Yang JS, et al. 2014. P53-regulated long noncoding RNA TUG1 affects cell proliferation in human nonsmall cell lung cancer, partly through epigenetically regulating HOXB7 expression. Cell Death Dis 5: e1243.

Zhang A, Zhao JC, Kim J, Fong KW, Yang YA, Chakravarti D, Mo YY, Yu J. 2015. LncRNA HOTAIR enhances the androgen-receptor-mediated transcriptional program and drives castration-resistant prostate cancer. Cell Rep 13: 209-221.

Zheng GX, Do BT, Webster DE, Khavari PA, Chang HY. 2014. Dicer-microRNA-Myc circuit promotes transcrip- tion of hundreds of long noncoding RNAs. Nat Struct Mol Biol 21: 585-590.

Zhou Y, Zhong Y, Wang Y, Zhang X, Batista DL, Gejman R, Ansell PJ, Zhao J, Weng C, Klibanski A. 2007. Activation of p53 by MEG3 noncoding RNA. J Biol Chem 282: 24731-24742.

Zhou J, Wan J, Gao X, Zhang X, Jaffrey SR, Qian SB. 2015. Dynamic $\mathrm{m}^{6} \mathrm{~A}$ mRNA methylation directs translational control of heat shock response. Nature 526: 591-594.

Zhu Y, Rowley MJ, Bohmdorfer G, Wierzbicki AT. 2013. A SWI/SNF chromatin-remodeling complex acts in noncoding RNA-mediated transcriptional silencing. Mol Cell 49: 298-309. 


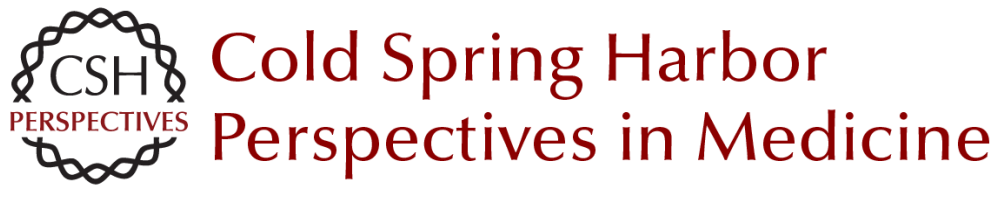

\section{Long Noncoding RNAs: At the Intersection of Cancer and Chromatin Biology}

Adam M. Schmitt and Howard Y. Chang

Cold Spring Harb Perspect Med 2017; doi: 10.1101/cshperspect.a026492 originally published online February 13, 2017

Subject Collection Chromatin Deregulation in Cancer

Mixed-Lineage Leukemia Fusions and Chromatin

in Leukemia

Andrei V. Krivtsov, Takayuki Hoshii and Scott A. Armstrong

Targeting Cancer Cells with BET Bromodomain Inhibitors

Yali Xu and Christopher R. Vakoc

The Role of Nuclear Receptor-Binding SET

Domain Family Histone Lysine Methyltransferases

in Cancer

Richard L. Bennett, Alok Swaroop, Catalina Troche, et al.

SETting the Stage for Cancer Development:

SETD2 and the Consequences of Lost Methylation Catherine C. Fahey and lan J. Davis

ATRX and DAXX: Mechanisms and Mutations Michael A. Dyer, Zulekha A. Qadeer, David Valle-Garcia, et al.

DNMT3A in Leukemia Lorenzo Brunetti, Michael C. Gundry and Margaret A. Goodell

Oncogenic Mechanisms of Histone H3 Mutations Daniel N. Weinberg, C. David Allis and Chao Lu

Nonhistone Lysine Methylation in the Regulation of Cancer Pathways

Scott M. Carlson and Or Gozani
TET2 in Normal and Malignant Hematopoiesis

Robert L. Bowman and Ross L. Levine

Long Noncoding RNAs: At the Intersection of Cancer and Chromatin Biology Adam M. Schmitt and Howard Y. Chang

DNA Hypomethylating Drugs in Cancer Therapy Takahiro Sato, Jean-Pierre J. Issa and Patricia Kropf

The Chromodomain Helicase DNA-Binding Chromatin Remodelers: Family Traits that Protect from and Promote Cancer Alea A. Mills

Exploitation of EP300 and CREBBP Lysine

Acetyltransferases by Cancer Narsis Attar and Siavash K. Kurdistani

Histone Lysine Demethylase Inhibitors Ashwini Jambhekar, Jamie N. Anastas and Yang Shi

Cohesin Mutations in Cancer Magali De Koninck and Ana Losada

MLL3/MLL4/COMPASS Family on Epigenetic Regulation of Enhancer Function and Cancer Christie C. Sze and Ali Shilatifard

For additional articles in this collection, see http://perspectivesinmedicine.cshlp.org/cgi/collection/ 